Nowoczesne Systemy Zarządzania Zeszyt 12 (2017), nr 1 (styczeń-marzec) ISSN 1896-9380, s. 25-37

Modern Management Systems Volume 12 (2017), No. 1 (January-March) ISSN 1896-9380, pp. 25-37

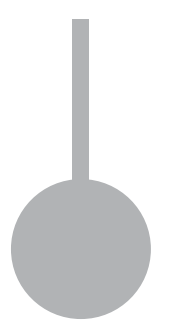

Instytut Organizacji i Zarządzania

Wydział Cybernetyki

Wojskowa Akademia Techniczna

w Warszawie

Institute of Organization and Management

Faculty of Cybernetics

Military University of Technology

\title{
Specyfika komunikacji \\ w środowisku wojskowym
}

\section{Specificity of the communication in the military environment}

\author{
Julia Nowicka \\ Wyższa Szkoła Menedżerska w Warszawie \\ e-mail: julia.nowicka.jn@gmail.com
}

\begin{abstract}
Abstrakt: Zasady komunikacji dotyczą każdego człowieka i w każdej dziedzinie jego życia znajdują zastosowanie. Autorka opracowania wskazuje na podobieństwo, podczas okolicznościowych wystąpień publicznych, stylu wypowiedzi żołnierzy ze stylem dziennikarskim czy naukowym, wskazując na wspólny oszczędny i konkretny profil wypowiedzi. Stawia ponadto tezę, że różnorodność stylu wypowiedzi kadry kierowniczej w wojsku cechuje głównie kod parajęzykowy (tzn. melodyka, ton, brzmienie głosu itp.), nie zaś zwięzłość, prostota oraz brak redundancji. Te, zdaniem autorki, cechują generalnie dzisiejsze społeczeństwo oparte na szybkim, obrazowym komunikowaniu się, obecnym np. w mediach, co wymusza używanie języka krótkiego, wręcz skrótowego. Zasada prostoty obowiązuje zatem w każdej specjalizacji publicznego użycia języka (prócz zastosowań literatury pięknej, aktorstwa i sztuki) i tym samym nie może być zarezerwowana tylko dla środowiska armii. W opracowaniu poruszono kwestię wulgaryzmów i zasadności zgłębiania zasad sztuki komunikacji wśród kadry kierowniczej wojska. Skupiono się zatem na właściwościach szeroko rozumianych kompetencji komunikacyjnych związanych z ekspozycją publiczną oficera.
\end{abstract}

Słowa kluczowe: komunikacja, oficer, wystąpienia publiczne, język, zasady

Abstract: Principles of the communication concern every man and in every field of his life are finding application. The author of the study shows, during occasional public appearances, the statement of soldiers the style to resemblance with the journalistic style whether scientific, pointing at the shared economical and specific profile of the statement. Moreover a paralinguistic code is putting the thesis that the diversity of the style in the army is characterizing statements of the senior staff mainly (i.e. melodic pattern, tone, sound of the voice and the like) not whereas the conciseness, the simplicity and the lack of the redundancy. These, in opinion of the author, are characterizing the today's society based on fast, vivid announcing generally oneself, for those present e.g. in the media what is forcing into using the short, simply brief tongue. And so the principle of the simplicity is applicable in every spe- 
cialization of public using the tongue (apart from applications of the literature, the acting and the art) and in the process cannot be booked only for the environment of the army. In the study an issue of vulgarisms and legitimacies of exploring principles of the art of the communication amongst the senior staff of the army were addressed. And so they concentrated on the properties of widely understood communications competence associated with the public exposition of the officer.

Keywords: communication, officer, public appearances, tongue, principles

\section{Wstęp}

Zgłębianie problematyki z obszaru kompetencji komunikacyjnych kadry kierowniczej skłoniło autorkę opracowania do poszukiwań literatury przedmiotu, traktującej o języku i charakterystyce jego występowania w środowisku wojskowym. Niestety, pomimo oczekiwań, nie udało się zgromadzić obszernej literatury, co wskazywać może na kilka ewentualności:

- po pierwsze, być może obszar podjętej problematyki nie został wnikliwie zbadany i opisany (co mogło mieć miejsce z rozmaitych powodów);

- po drugie, być może nie ma potrzeby eksplanacji i eksplikacji tematyki, gdyż mnogość opracowań dotyczących użycia języka ojczystego wyczerpuje niedosyt poznawczy;

- po trzecie, być może autorka nie dotarła do szeregu opracowań, co mogłoby skutkować zaburzeniem obrazu sytuacji.

Zakładając możliwość zaistnienia w jakimś procencie każdego z wymienionych wariantów, wydaje się istotną próba ich poznania. Przeprowadzenie owego działania było związane z realizacją procesu badawczego obejmującego reprezentatywną próbę 396 oficerów Wojsk Lądowych.

Badania własne potwierdziły założenia teoretyczne symbolizmu interakcyjnego i goffmanowskiej perspektywy dramaturgicznej, według których badanie rzeczywistości porozumiewania się ludzi jest dziedziną różnorodną i zmienną. Nie lada trudności nastręcza chęć jej naukowego poznania. Jednak podejmowanie próby takich działań jest potrzebne dla usprawnienia funkcjonowania jednostki w grupie, tudzież pogłębienia wiedzy o komunikacji i procesie związanym z rzetelnością i trafnością jej poznania.

Badając elementy procesu komunikacji, a konkretnie akcentując jej wycinek związany z przemówieniami publicznymi, skupiono się na instytucji zaufania publicznego jaką jest Wojsko Polskie. Według S. Marciniaka aktywność komunikacyjna oparta jest o rozumienie języka jako instrumentu oddziaływania, jako tworzywa i jako efektu wytworu społecznego. W tym ujęciu „praktyka wojskowa stanowi rozległy poligon lub, jeśli kto woli - gigantyczne laboratorium językowe. Cokolwiek się w jej zakresie odbywa, dotyczy też języka" (Marciniak, 1987, s. 209).

Żołnierz przede wszystkim służy, tzn. działa na rzecz obrony niepodległości i suwerenności kraju (Konstytucja Rzeczypospolitej Polskiej, 1997, art. 26), jednak jak wskazuje cytowany wcześniej autor, twórca obszernej charakterystyki języka wojskowego: „Kultura języka kadry zawodowej, a także zadowalający poziom 
kultury języka zbiorowości żołnierskiej są w stanie znacznie dopomóc wojsku jako całości w wywiązywaniu się z podstawowych zadań” (Marciniak, 1987, s. 188). Język w tym ujęciu jest traktowany jako instrument istotny w uprawianiu zarówno sztuki wojennej, jak i praktyki dowodzenia.

Język jest wizytówką przemawiającej osoby. U prelegenta ocenia się nie tylko przedstawioną wartość merytoryczną wystąpienia, lecz także prawidłowe użycie języka, którym się posługuje. Mowa, głos i sposób wykorzystania języka są środkami do osiągnięcia celu, jakim jest wywołanie na słuchaczach określonego wrażenia. Mimo, iż są to tylko elementy składowe procesu komunikowania, należy je doskonalić, by móc maksymalnie czerpać z ich potencjału.

Deskrypcja pełni języka, którym operują żołnierze jest nie lada wyzwaniem. Dla potrzeb niniejszego opracowania skupiono się na pewnym fragmencie rzeczywistości komunikacyjnej. Rozpatrywano zatem nie codzienność werbalną służących, ale skupiono się na okolicznościowych przemówieniach publicznych. Za takie uznano „dłuższe lub krótsze oracje, które mają na celu wywołanie pewnych wzruszeń, stworzenie określonego nastroju. Mowy okolicznościowe realizują głównie funkcję ekspresywną, wyzwalają emocje i uczucia. Są stałym elementem życia społecznego, towarzyskiego i rodzinnego, a zarazem - w pewnym sensie - przejawem tradycji narodowej" (Burakowski, 1995, s. 19). Założono zatem, że mowy okolicznościowe łączą umiejętności ekspresji pozajęzykowej (elementy tzw. mowy ciała), parajęzykowej (tempo, czas wypowiedzi, brzmienie głosu, modulacja, pauza wyrazowa, embolofrazja itp.) i językowej (elementy komunikacji werbalnej) (Kaczmarek, 2003, s. 11-25). Istotą niniejszego opisu nie było objęcie swym zainteresowaniem języka typowego dla wykonywania rozkazów, składania meldunków itp. Skupiono się na właściwościach szeroko rozumianych kompetencji komunikacyjnych związanych z ekspozycją publiczną oficera.

Przemówienia okolicznościowe dają szansę zaprezentowania umiejętności komunikacyjnych, ponieważ często dotyczą uroczystości, w których publiczność stanowi nie tylko brać żołnierska, lecz także rzesza osób cywilnych. Takie audytorium $z$ jednej strony nie narzuca kalki prezentacji środowiskowej, z drugiej jednak strony ujawnia te elementy kultury organizacyjnej wojska, które są na tyle silne, że odznaczają się na neutralności stylu przekazu publicznego, podobnie jak zaznacza swą indywidualność stylu kultura mów, np. księży. Nawet gdyby przemawiali oni w cywilnym stroju, z dużym prawdopodobieństwem można by rozpoznać stylistykę mowy osoby duchownej.

\section{Charakterystyka wypowiedzi}

Na podstawie analizy krytycznej literatury przedmiotu można stwierdzić, że język w wojsku, zarówno ten w dokumentach, jak i w codziennym użyciu, jest zróżnicowany i uzależniony od funkcji nominatywnych czy komunikacyjnych, 
które w danym momencie realizuje. Ogólnie „język wojskowy” jest „Zwięzły, konkretny, imperatywny, sformalizowany i schematyczny, co czyni go sprawnym" (Wolańska, 2007, s. 99).

Tak zwana gwara żołnierska jest ściśle związana ze społecznym kontekstem jej występowania, może być ona zatem wg rozmaitych klasyfikacji traktowana jako odmiana języka zawodowego lub jako typ tzw. gwary młodzieżowej (wg S. Dubisza). „Cechą tych gwar jest szczególna niekomunikatywność, wypływająca z tendencji do skrótowego formułowania wypowiedzi oraz z używania pewnych frazeologizmów, których źródło leży w sferze pozajęzykowej" (Marciniak, 1987, s. 203).

Analizując przemówienia okolicznościowe zawarte w rozkazach wojskowych, językoznawcy związani z Radą Języka Polskiego obliczyli wskaźniki: zrozumiałości słownictwa, składni, abstrakcyjność zwrotów, poziom trudności tekstu, a także nominalizację. Analiza wykazała, że na przestrzeni lat 1983-2004, język rozkazów okolicznościowych „zmienił się i usprawnił” (Wolańska, 2007, s. 109). Jest on bardziej konkretny, o mniejszym stopniu abstrakcyjności i zwiększonej przystępności tekstu, na co wpływa stosowanie łatwiejszej składni zdania. Cechuje go zatem ogólna poprawność, zrozumiałość i komunikatywność językowa. Język wojskowy (klasyczny język wojskowy) wykazuje przede wszystkim funkcjonalność swej postaci, co stanowi jego atut komunikacyjny.

Analizując literaturę przedmiotu można odnieść wrażenie, że język wojskowy (również podczas przemówień okolicznościowych) traktowany jest jako swoista odmiana kodu porozumiewania się, która jest typowa dla środowiska wojskowego, będąc środowiskowo-zawodową odmianą rodzimego języka (Marciniak, 1987, s. 38). $\mathrm{Z}$ tezą powyższą jednak autorka niniejszego opracowania nie może się zgodzić, gdyż w drodze współczesnego poznania naukowego jest zbyt wiele wątpliwości dotyczących takiego stanowiska.

Badania własne pokazały, że podczas realizacji mowy okolicznościowej stopień nominalizacji nie jest tak charakterystyczny jak w języku regulaminowym, choć taką obecność można zarejestrować. Cechą przemówień okolicznościowych kadry kierowniczej wojsk lądowych będzie za to m.in. swoiste napięcie aparatu mowy, twardy atak dźwięku i skromność używania pauz. Między innymi te cechy, a nie zwięzłość komunikacyjna wypowiedzi, stają się wyróżnikiem stylu „mówcy oficera” (Nowicka, 2016).

\section{Zwięzły język jako styl wypowiedzi}

Konkret wypowiedzi, stanowczość i zwięzłość. Takie wydają się być stereotypowe określenia języka, którym posługuje się żołnierz. Tezę tę sformułowano na podstawie zgromadzonej literatury przedmiotu i w wyniku przeprowadzonych 
empirycznych badań własnych. Zatem adekwatnym zachowaniem komunikacyjnym w tym ujęciu będą wytyczne:

- Nie czyń rozbudowanych wstępów.

- Używaj prostego języka i prostych konstrukcji zdaniowych.

- Mów zwięźle, logicznie i na temat.

- Unikaj dygresji i pustych wyrażeń, które nie niosą żadnych treści.

- Dawaj konkretne przykłady.

- Kontroluj czas i tempo swojej wypowiedzi (Bonikowska, Ostrowska, 2000, s. 179).

Wyszczególnione powyżej zasady opisujące żołnierską praktykę słowną pochodzą jednak nie z podpunktów ceremoniału wojskowego a z kompendium wskazówek dla prawidłowego wypowiadania się w środowisku telewizyjnym. Dlaczego? Ponieważ ten sam zestaw identyfikatorów stylu okazuje się cechować każdego dobrego komunikatora, niezależnie od środowiska, w którym jest on zakorzeniony.

Dla przykładu: British Computer Society stawia wymogi komunikowania się językiem „jasnym, zwięzłym i poprawnym” (Warmer, 2008, s. 60). W sztuce komunikowania się i zarządzania, w pedagogice, także w dziennikarstwie wytyczne zdają się mieć wspólny mianownik, który można opisać słowami: „tylko precyzyjne, logiczne i zwięzłe wypowiedzi mają szansę na emisję" (Bonikowska, Ostrowska, 2000, s. 179).

W świecie nauki także podkreśla się konieczność przekazywania informacji w sposób logiczny i prosty, czasem używa się w tym celu określenia - ekonomiczny. Jasność stylu rozumiana jest jako dostosowanie słownictwa, leksyki i użytej składni (głównie rodzaju zdań złożonych) do poziomu odbiorcy (Pieter, 1967, s. 232233). Środowisko naukowe od zarania (czyli można przyjąć od starożytnych pism Arystotelesa, zwanego ojcem retoryki) postuluje prostotę i zwięzłość językową. Pomagają one uściślić znaczenie wypowiadanych słów, co jest domeną logiki, zwanej królową wszystkich nauk. Szkodliwe używanie wieloznaczności werbalnego przekazu wykorzystywane było już w starożytności przez sofistów, którzy udowodniali swą niepochlebną, bo szeroko manipulacyjną działalnością, potrzebę konkretnego, prostego i zrozumiałego przekazu opartego na prawach logiki (Ajdukiewicz, 1956, s. 6-8).

Ponad 100 lat temu J. St. Mill pisał: „Nawet w rozmowie potocznej idee, związane ze słowem «logika», obejmują co najmniej precyzję języka i dokładność klasyfikacji (...)" (Mill, 1962, s.13).

Idolami rynku są nazwane przez Bacona błędy językowe, niewłaściwie tworzona terminologia, nazywanie rzeczy czy wreszcie zjawisk nieistniejących. Bacon wskazuje, że źle dobrane słowa wpływają na rzeczywistość człowieka i w swoisty sposób ograniczają go, „krępują rozum”. Stąd postulował on płynność porozumiewania się zbudowaną na prostocie języka, zwartości komunikatów i dostosowaniu treści do odbiorcy. Ta uwaga, wg Bacona, tyczy się każdego środowiska, nawet naukowego. „Słowa całkowicie zadają zamach rozumowi, wszystko mącą i przywodzą ludzi do niezliczonych jałowych kontrowersji i wymysłów” (Bacon, 1955, s. 68). 
Prostota stylu związana jest z używaniem jak najprostszych konstrukcji językowych z dostępnego zasobu językowego (Pelc, 2012, s. 83). „Chodzi głównie o to, by wywody uczonego, były równoznaczne z tym, co rzeczywiście chciał powiedzieć; by wyrażał się zwięźle, tj. używał tylko tylu wyrażeń, ile jest niezbędne dla trafnego oddania swych myśli; by odwoływał się do w miarę prostych i adekwatnych wyrazów i zwrotów w wypowiadaniu tego, co ma do powiedzenia; by wreszcie liczył się z zasobem współczesnej polszczyzny i wykluczał dwuznaczne rozumienie używanych przez siebie pojęć" (Łobocki, 2001, s. 22).

O zalecaniu jasności, klarowności, konkrecie, prostocie i zwięzłości można dowiedzieć się zgłębiając tajniki tworzenia przyjaznych i ciekawych dla odbiorcy tekstów pisanych (Wierzbicka, Wolański, Zdunkiewicz-Jedynak, 2008, s. 7). Poza tym literatura przedmiotu obfituje w twierdzenia, że już dziecko chce „by odpowiedzi (na jego pytania) były krótkie i stanowcze, zrozumiałe, jednobrzmiące, poważne, uczciwe" (Koć-Seniuch, 1997, s. 165). Znamienite, że te same cechy przedstawiali badani (Nowicka, 2016) opisując specyfikę komunikacji w wojsku.

Powszechnie uznaje się, że język wojskowy pozbawiony jest zwrotów metaforycznych i malowniczych porównań. Trudno się z tym nie zgodzić, co ma swoje następstwa. Bowiem jeśli tak jest, to wpisuje się on tym samym w styl prosty $(\text { Kucz, 2008) })^{1}$, przejrzysty i naturalny, który skupia się na aspekcie utylitarnym, nie artystycznym. Jednak, jak mawiają badacze przedmiotu, wykorzystując styl prosty nie chodzi o to, by zrezygnować z wszelkich trików oratorstwa, ale by ukryć je umiejętnie w tekście i nie epatować nimi, a po prostu czerpać z siły ich oddziaływania. „Wszystko, co napuszone, niezwykłe i zbyt ozdobne jest nienaturalne, czyni wrażenie sztuczności, a zatem nie budzi wśród słuchaczy zaufania do przemawiającego" (Kucz, 2008, s. 20).

Mowa w tej konwencji jest przede wszystkim skuteczna i bliska potocznemu stylowi wypowiadania się, nierzadko obfitująca w wulgaryzmy. „Grubiaństwo zwykle jest dowodem własnej nieumiejętności i niszczy punkt honoru, który duszą żołnierza być powinien" (Hołówko, 1996, s. 48). T. Hołówko opisując charakter wojska w czasie rozbiorów i tuż po nich, wskazuje, że rozpowszechnione używanie wulgaryzmów i lżenie nimi publicznie niższych rangą jest zaszczepione z wojska rosyjskiego, bo w armii napoleońskiej nie było dopuszczalne. Tyczy się to całości pojęcia płazowania, czyli szturchania i publicznego znieważania, bicia. Również nieoczytanie oficera polskiego było kalką kształcenia zaczerpniętą z armii rosyjskiej, gdzie „oficer prenumerujący gazetę należał do wyjątków, źle był widziany przez starszyznę i wykpiwany przez kolegów” (Hołówko, 1996, s. 49).

1 Za czołowego przedstawiciela stylu prostego uważa się Lizjasza (450-380 p.n.e.), także najwięksi mówcy czasów antycznych lubowali się w tej stylistyce, np. Juliusz Cezar (100-44 p.n.e.), Demostenes (384-322 p.n.e.) czy Marek Aureliusz Cyceron (106-43 p.n.e.), por. K. Kumaniecki, Literatura rzymska. Okres cyceroński, Warszawa 1977; Kucz, Retoryka i oratorstwo w starożytności, [w:] M. Barłowska, A. Budzyńska-Daca, P. Wilczek (red. nauk.), Retoryka, PWN, Warszawa 2008. 
Chyba naiwnością byłoby sądzić, że wulgaryzmy, które są uznawane (również dzisiaj) przez samych żołnierzy za element ich kultury środowiskowej, można by było zlikwidować, choć zacnym był zwyczaj próby unikania ich przez żołnierzy w okresie dwudziestolecia międzywojennego, o czym wspomina Hołówko: „Energiczną walkę rozpocząć powinni oficerowie z tak przebogatym leksykonem «skurwysynowstwa», tak, niestety, od góry do dołu panoszącego się w wojsku. Dziwne i smutne wrażenie robi ten oficer, który wchodzi do koszar ze «skurwym synem» na ustach i z nim wychodzi" (Hołówko, 1996, s. 85).

Proponuje się zatem kwestię wulgaryzmów rozpatrywać nie w kategorii niepoprawności językowej, a wątpliwej estetyki wypowiedzi (Wierzbicka, Wolański, Zdunkiewicz-Jedynak, 2008, s. 39). Optymistyczne w tym ujęciu wydają się być wyniki badań, którym przyświeca wniosek respondentów, iż przełożeni w $16 \%$ zachowują się w stosunku do nich grubiańsko i używają wulgarnego języka. Połowa badanych przyznała, że robią to rzadko (Wojskowe Biuro Badań Społecznych, 2013, s. 24).

\section{Okolicznościowe przemówienia kadry kierowniczej}

O zasadności i przyczynie skupienia się w prezentowanym opracowaniu na okolicznościowych przemówieniach pisano powyżej, pora zatem zastanowić się, co stanowi istotę dobrego przemówienia. Zdaje się, że może być nią takie użycie kompetencji komunikacyjnych, które zapewni prezentację wywołującą pełne zaangażowanie w daną sytuację u odbiorców (Goffman, 2006, s. 117). Kierujący zespołem ludzi w wojsku odgrywa role społeczne traktowane jako „zestaw zachowań kojarzonych z określoną pozycją w systemie społecznym" (Harre i Lamb, 1986). „Od osoby zajmującej daną pozycję oczekuje się postępowania odpowiadającego tej roli” (Leary, 2005, s. 95).

\subsection{Specyfika środowiska}

Bariery komunikacyjne $\mathrm{w}$ analizowanej organizacji stanowią m.in. społeczne uwarunkowania wynikające $\mathrm{z}$ heteronomii instytucji, co implikuje wystąpienie zniekształceń komunikacyjnych w postaci języka rozkazów i dyrektyw. Mimo, iż w mowach okolicznościowych istnieje przestrzeń do względnej swobody wypowiedzi, specyfika środowiskowa naznacza również i tę aktywność, co ma wyraz na każdym poziomie prezentacji (językowym, parajęzykowym i pozajęzykowym).

Z badań własnych wyłonił się wniosek, że w opinii badanych oficerów, w wystąpieniach publicznych kategorią odmienną $\mathrm{w}$ stosunku do środowiska cywilnego jest specyficzne audytorium, złożone $\mathrm{z}$ ludzi pochodzących $\mathrm{z}$ rozmaitych środowisk i miejsc zamieszkania. Przeświadczenie żołnierzy o wyjątkowości środowiska zawodowego, które reprezentują, wpisuje się w zinternalizowane poczucie kultury 
organizacyjnej. Jednak nie jest to argument wystarczający do racjonalnego przyjęcia prezentowanego odczucia, bowiem różnorodność audytorium jest cechą występującą $\mathrm{w}$ większości masowych przemówień lub w świecie polityki, a także mediów. I tak, J. Filipowicz jako dziennikarz radiowy zauważa: „Musimy się liczyć $\mathrm{z}$ różnym poziomem intelektualnym naszych odbiorców, różnym wykształceniem i po prostu nawet $\mathrm{z}$ różnym rozumieniem słów, a czasami $\mathrm{z}$ kompletnym brakiem ich zrozumienia" (Filipowicz, 2000, s. 215).

Paradoksalnie różnorodność publiki i związane z tym niedogodności dla prelegenta stanowią wartość rozwojową. Mogą wzmocnić jego kunszt, są więc mu potrzebne, gdyż narzucają mu konieczność utrzymania wysokiego poziomu samokontroli. Zjawisko „obserwacyjnej samokontroli zachowania” można nazwać zdolnością adekwatnego zachowania do okoliczności, zbudowanego na oglądzie zaobserwowanej rzeczywistości. Do tego celu konieczna jest umiejętność interpretowania zachowania partnerów interakcji, by określić ich technikę autoprezentacyjną. „Osoby o wysokiej samokontroli zachowania zdają się odnosić większe sukcesy w sytuacjach interakcji społecznych. Są lepszymi kierownikami i zarządzającymi, z uwagi na elastyczność zachowań, którą prezentują" (Nowicka, 2015, s. 139). Dzieje się tak za sprawą dysponowania przez nich wiedzą i umiejętnościami z zakresu procesów grupowych i posiadanych kompetencji komunikacyjnych. „Osoby o silnej samokontroli sprawdzają się w tej roli względnie lepiej” (Caldwell i O’Reilly, 1982) (Leary, 2005, s. 78).

\subsection{Korpus oficerów starszych i młodszych}

Jedną z hipotez cytowanych badań własnych, było stwierdzenie, iż „silna kultura organizacyjna wojska nie wytworzyła znaczącej różnicy w zakresie posiadanych kompetencji pomiędzy starszymi i młodszymi oficerami”. Wyniki badań, choć niejednoznacznie, potwierdzają przyjęte założenie. Nieostrość dotyczy pojawienia się analiz wskazujących m.in., że oficerowie starsi lepiej niż oficerowie młodsi oceniają swoje wystąpienia publiczne przed podwładnymi, oraz rzadziej, niż oficerowie młodsi, sygnalizują brak umiejętności obsługi mikrofonu. Nie wykazano znacznych różnic w podejściu badanych grup do problemu odczuwania tremy. Nieznacznie więcej oficerów młodszych chciałoby skorzystać z konsultacji logopedycznej poprawiającej jakość komunikowanej substancji fonicznej. Porównując obie grupy, ogólnie lepiej swoje umiejętności gestykulacji oceniają oficerowie starsi. Kuszące byłoby wyartykułowanie uproszczenia, że im wyższy stopień wojskowy tym większe zadowolenie i pewność siebie podczas wystąpień publicznych, jednak trafność i rzetelność badawcza zmusza do ostrożności we wnioskowaniu z racji tego, iż większość różnic była nieznaczna, na granicy albo w przedziale błędu statystycznego. Wydaje się zatem, że w kategorii różnic pomiędzy korpusem oficerów starszych i młodszych zasadnym jest mówić raczej o tendencjach niż prawidłowościach. 


\subsection{Specyfika prezentacji w przemówieniach okolicznościowych}

Jak wspomniano wcześniej badania własne pokazały, że podczas realizacji mowy okolicznościowej stopień nominalizacji nie jest tak charakterystyczny jak w języku regulaminowym, choć taką obecność można zarejestrować. Cechą przemówień okolicznościowych kadry kierowniczej wojsk lądowych jest swoiste napięcie aparatu mowy, twardy atak dźwięku i oszczędność używania pauz.

Ogólnie rzecz ujmując można odnieść wrażenie, że obszar kodu pozajęzykowego podczas przemówień publicznych oficerów jest bardzo skromnie zagospodarowany. Gest, interakcja, funkcje integracyjne przemówień są w omawianej sferze niedoceniane. Utrudnia to nie tylko utrzymanie kontaktu $\mathrm{z}$ widzem, ale wręcz jego nawiązanie. Pewien niedosyt pozostawia sytuacja zarządzania swym wizerunkiem, zauważalna w kategoriach takich jak:

- dynamika ruchu;

- kontakt wzrokowy;

- praca z mikrofonem;

- korzystanie z notatek;

- wykorzystywanie proksemiki.

W sferze parajęzykowej podczas realizacji okolicznościowych przemówień publicznych na uwagę zasługują następujące cechy:

- nieznaczność występowania embolofrazji, tzw. jęków namysłu (eeee, yyyy, aaaa pomiędzy wymawianymi wyrazami);

- nieznaczność używania zwrotów retardacyjnych;

- częste brzmienie nakazowe;

- częsty brak próby wywołania dialogiczności z audytorium;

- ogólnie mowy mieszczą się w konwencji przewidywalności (cechuje je niski poziom innowacji retorycznej i zaskoczenia).

Jedną z omawianych cech kodu parajęzykowego jest brzmienie nakazowe wypowiedzi. Samo w sobie może być ono oznaką siły i pewności siebie, czyli cech potencjalnie pożądanych u oficera prelegenta. Jak wskazują badania T.R. Bacona, „osoby, które mówią zdecydowanym głosem, są również dwa razy skuteczniejsze niż te o łagodnym tonie. Asertywność zwiększa skuteczność wpływu trzykrotnie, a pewność siebie czterokrotnie" (Bacon, 2013, s. 122).

W świetle przeprowadzonych badań własnych wydaje się jednak, że preferowane przez żołnierzy: nakazowość brzmienia (parajęzykowość) połączona $\mathrm{z}$ wielce oszczędną aktywnością wizualną (pozajęzykowość) i zwięzłością przekazu (językowość) mogą wpływać na ograniczenie interakcyjności i wzmaganie wrażenia arbitralności głoszonych treści. Taki styl prezentacji może być wytłumaczeniem głoszonej przed laty tezy A. Zwolińskiego, iż arbitralność „nie dopuszcza dyskusji, przeciwnych argumentów, staje się bronią bezpośredniego ataku" (Zwoliński, 2003, s. 184). 
Praca nad umiejętnościami komunikowania się jest istotna w połączeniu ze świadomością oddziaływania słowa na ludzi. Ponad jedna czwarta badanych żołnierzy wskazała $\mathrm{w}$ jednym $\mathrm{z}$ badań WBBS, że doświadczyła publicznego ośmieszenia lub poniżenia (Wojskowe Biuro Badań Społecznych, 2013, s. 5), co wydaje się być sytuacją wielce niepożądaną.

Wydaje się, że właśnie kategoria przemówień okolicznościowych w wojsku daje (bardzo potrzebne żołnierzom) obszar i szansę na zachowanie spontaniczności i indywidualności. Tych, które stoją w opozycji do dyrektywnych, sztywnych zachowań kodeksowych, typowych dla zhierarchizowanej instytucji wojska. W takim ujęciu swoboda decyzyjna (co do użytych środków komunikacyjnych) i korzystanie z kontekstu, podobnie jak etyka sytuacyjna, tworzą nową wartość komunikacyjnego zachowania (Lazari-Pawłowska, 1994, s. 194-195).

Przemawianie $\mathrm{w}$ środowisku wojskowym jest często oparte na przedstawianiu faktów, które stają się kanwą mowy. Badani, podczas realizowanego projektu badawczego, wyraźnie wskazali, że najistotniejszym elementem przemówień jest ich treść, co zobrazowano na wykresie nr 1 . Wielce interesującą kwestią jest brak zgodności udzielonych odpowiedzi z tendencją, którą w nauce wskazał badacz A. Mehrabian. Sformułowana przez niego w latach 70. XX w. teoria została wielokrotnie zweryfikowana pozytywnie przez szereg badaczy. Za wiodący segment prezentacji publicznej, tej związanej z emocjonalnością przekazu (zatem właśnie odnoszącej się do kategorii przemówień okolicznościowych) uznaje się bowiem po pierwsze: mowę ciała, po drugie: ton głosu, po trzecie: treść wystąpienia. Zupełnie inną hierarchię uznają badani oficerowie, którzy wyróżniają przede wszystkim treść, potem ton głosu, którym operują, by wreszcie oprzeć się na mowie ciała.



Wykres 1. Ocena podstawowych elementów przemówień publicznych w oczach kadry kierowniczej Wojsk Lądowych

Źródło: J. Nowicka, Kompetencje komunikacyjne kadry kierowniczej Wojsk Lądowych, AON, Warszawa 2016, s. 219 
Próba odniesienia się do wskazanej różnicy wyników badań jest tematem obszernym, wykraczającym poza ramy niniejszego opracowania i stanowi treść monografii autorskiej, jednak konkludując podjęty wątek należy zauważyć, że w świetle badań naukowych najistotniejsze jest zbudowanie więzi ze słuchaczem, dopiero w kolejnych partiach należy przedstawić fakty lub/i płynące z nich przesłanie. „Fakty nie mówią same za siebie, ktoś daje im mówić przez wybór, aranżowanie i podkreślenia" (Abramowicz, 2000, s. 131).

\section{Podsumowanie}

Zasady komunikacji dotyczą każdego człowieka i w każdej dziedzinie jego życia znajdują zastosowanie. Świadczy to o ich uniwersalnym charakterze. Siła kompetencji komunikacyjnych, jest w dzisiejszej teorii zarządzania coraz głośniej poruszaną kwestią. Z. Ciekanowski sklasyfikował owe umiejętności jako kluczowe w zestawie kompetencji pracowniczych, mających wpływ na budowanie poczucia bezpieczeństwa personalnego (Ciekanowski, 2014, s. 100). Warto przy tym podkreślić, że zasady rządzenia wojskowego od cywilnego niczym się nie różnią (Bocheński, 1993, s. 106-107).

Właściwość dzisiejszego społeczeństwa oparta na szybkim, obrazowym komunikowaniu się, obecnym w mediach, wymusza używanie języka krótkiego, wręcz skrótowego. Zasada prostoty obowiązuje zatem w każdej specjalizacji użycia języka publicznego (za wyjątek można tu uznać zasady sztuki, tzn. literatury pięknej, aktorstwa itp.).

Tak jak historia różnie ocenia bitwy i wojny, tak różnie notowane są kampanie prezentacyjne mówców. Uzależnione jest to od faktów społecznych, emocji, które audytorium zapamięta. Wyrazistość i sugestywność mówcy odbija ślad w odbiorze słuchaczy. Zdarza się jednak, że mówca o niedoskonałym warsztacie retorycznym zostawi w pamięci publiczności głównie te wspomnienia, które świadczą o jego indolencji w temacie. Istotą byłoby takie formowanie znaków językowych, parajęzykowych i pozajęzykowych, by maksymalnie sprzyjały całkowitemu zaangażowaniu słuchaczy (Goffman, 2006, s. 117).

Mimo uniwersalności zastosowania i potrzeby użycia kompetencji komunikacyjnych można wyróżnić pewne specyfiki prezentacyjne oparte o kulturę organizacyjną danej instytucji lub o subkulturę społeczną. W takim ujęciu można wyróżnić kategorię języka wojskowego.

Wzmacnianie kompetencji komunikacyjnych u żołnierzy nie ma na celu uczynienia $z$ nich nienagannych piewców mowy ojczystej, ani ukształtowania ich na pierwszych oratorów Rzeczypospolitej. Powinnością żołnierza jest przede wszystkim obrona kraju. Jednak przez samych zainteresowanych (proporcjonalnie do zajmowanego szczebla w hierarchii dowodzenia) kompetencje komunikacyjne, zaraz po 
merytorycznych i tych związanych z odpornością na sytuacje trudne, są uznane za istotne w funkcjonowaniu żołnierskim (Wojskowe Biuro Badań Społecznych, 2014).

Traktowanie umiejętności porozumiewania się w sposób czysto intuicyjny i mało istotny jest sprzeczne ze sztuką zarządzania i z powinnością oficera jako wzoru do naśladowania. Krótko mówiąc, pomijanie wagi kompetencji komunikacyjnych jest ryzykowne. „Z wszelkiego rodzaju ryzykiem można sobie radzić wykazując się zapobiegawczością i stosując praktyki obronne, ale całkiem uniknąć go nie można" (Goffman, 2006, s. 186).

Charakterystyczny opis oficera polskiego w trochę patetycznym i uduchowionym stylu jest typowy dla obrazu retoryki XVIII wiecznej Polski, gdzie po elokucyjnej erze związanej z Barokiem nastąpił czas powrotu do obrazu mówcy połączonego z cnotami obywatelskimi. Dziś wydaje się, że otwartość armii na techniki zarządzania oraz uniwersalność zwięzłości w mowach publicznych sprawiły, że cech charakterystycznych dla przemawiającej kardy kierowniczej (na przykładzie wojsk lądowych) można upatrywać nie w treści, a w sposobie jej przekazywania. Tu na czołowe miejsce wysuwa się specyficzna melodia i ton głosu, które czynią z kodu parajęzykowego znak charakterystyczny dla retorów - oficerów.

Istotną kwestią jest potrzeba posiadania przez oficerów nie tyko wiedzy i umiejętności sprawnego poruszania się w zagadnieniach retoryki, ale i odpowiedniego nastawienia do potrzeby kształcenia się w omawianym zakresie, jak i potrzeby pozytywnego nastawienia i odwagi do tego, by tworzyć i realizować pewne, motywujące wizje, oddziałujące na audytorium.

\section{BIBLIOGRAFIA}

[1] Ajdukiewicz K., 1956, Zarys logiki, wyd. PZWS, Warszawa.

[2] BACon F., 1995, Novum Organum, wyd. PWN, Warszawa.

[3] BACON T.R., 2013, Sposób na opornych. Skuteczne wywieranie wpływu, wyd. GWP, Sopot.

[4] BarŁowska M., Budzyńska-Daca A., Wilczek P. (red.), 2008, Retoryka, wyd. PWN, Warszawa.

[5] BocheŃski J.M., 1993, De Virtute Militari. Zarys etyki wojskowej, wyd. Philed, Kraków.

[6] Burakowski K., 1995, Sztuka przemawiania, Biuro Prasy i Informacji MON, Warszawa.

[7] Ciekanowski Z., 2014, Determinanty bezpieczeństwa personalnego $w$ zarządzaniu zasobami ludzkimi w nowoczesnej organizacji, wyd. PWST-E, Jarosław.

[8] Drzycimski A., 2000, Komunikatorzy, wplyw, wrażenie, wizerunek, Oficyna Wydawnicza Branta, Warszawa-Bydgoszcz 2000.

[9] Goffman E., 2006, Rytuał interakcyjny, wyd. PWN, Warszawa.

[10] Ноєówко T., 1996, Oficer polski, wyd. Czasopisma Wojskowe, Warszawa.

[11] Kaczmarek B., Markiewicz K. (red.), 2003, Komunikowanie się we współczesnym świecie, wyd. UMCS, Lublin.

[12] Kompetencje społeczne kadry dowódczej WP w kontekście realizacji zadań służbowych, Sprawozdanie $z$ badań, 2014, WBBS, Warszawa. 
[13] Konstytucja Rzeczypospolitej Polskiej z 2 kwietnia 1997 r.

[14] Kumaniecki K., 1977, Literatura rzymska. Okres cyceroński, Warszawa.

[15] Kwiatkowska H., Szybisz M. (red.), 1997, Komunikacyjne kompetencje zawodowe nauczycieli, wyd. PAN, Warszawa.

[16] Leary M., 2005, Wywieranie wrażenia na innych, wyd. GWP, Gdańsk.

[17] Łовоскі M., 2001, Wprowadzenie do metodologii badań pedagogicznych, Oficyna Wydawnicza „Impuls”, Kraków.

[18] MarciniaK S., 1987, Język wojskowy, wyd. MON, Warszawa.

[19] Mentzel W., 2009, Mistrzowska retoryka, Sekrety przekonujacych wystapień, Opolgraf SA, Flashbook.pl.

[20] Mill J. ST., 1962, System logiki, tom 1, wyd. 1, wyd. PAN, Warszawa.

[21] Nowicka J., 2015, Zarzadzanie kompetencjami komunikacyjnymi - autoprezentacja, „Zeszyty Naukowe Uniwersytetu Przyrodniczo-Naukowego w Siedlcach", nr 105, Seria Administracja i Zarządzanie (32) 2015, Siedlce.

[22] Nowicka J., 2016, Kompetencje komunikacyjne kadry kierowniczej Wojsk Ladowych, AON, Warszawa.

[23] Pelc M., 2012, Elementy metodologii badań naukowych, wyd. AON, Warszawa.

[24] Pieter J., 1967, Ogólna metodologia praca naukowej, Zakład Narodowy im. Ossolińskich, Wrocław.

[25] Relacje międzyludzkie i profilaktyka uzależnień (wiosna 2013), sprawozdanie z badań, 2013, WBBS, Warszawa.

[26] Środa M. (red.), 1994, O wartościach, normach i problemach moralnych, wyd. PWN, Warszawa.

[27] WARner T., 1999, Umiejętności w komunikowaniu się, wyd. ASTRUM, Wrocław.

[28] Wierzbicka E., Wolański A., Zdunkiewicz-Jedynak D., 2008, Podstawy stylistyki i retoryki, wyd. PWN, Warszawa.

[29] Wolańska E. (red.), 2007, Polszczyzna publiczna początku XXI wieku, Rada Języka Polskiego przy prezydium PAN, Warszawa.

[30] WoŁejszo J., 2008, Organizacja pracy kierownika w strukturach zhierarchizowanych, wyd. AON, Warszawa.

[31] Zwoliński A., 2003, Słowo w relacjach społecznych, WAM, Kraków. 